\title{
Settling and Unsettling the Transnational Legal Order of International Taxation
}

\author{
By Philipp Genschel and Thomas Rixen ${ }^{1}$
}

\section{TLOs as problem-solvers and problem-creators}

Transnational legal orders (TLOs) are formed to solve policy problems of a cross-border nature. In doing so, they often create new problems which trigger the formation of new TLOs. TLOs are problem solvers and problem creators at the same time. Partly at least, the problems requiring transnational legal ordering are endogenous. This is why the stream of problems requiring transnational attention is unlikely to ever dry up and why the ecology of TLOs is unlikely to ever reach a steady state. Hence, in order to understand how TLOs "originate, consolidate and constrain behavior" (Halliday \& Shaffer this volume: 2), it is important to take a broad and diachronic perspective. We have to look broadly at the field of related TLOs in order to understand how one TLO's solution becomes another TLO's problem, and we have to analyze the historical sequence in which problems are framed, taken up and solved because what happens first has crucial implications for what happens latter. Our historical analysis of transnational legal ordering in international taxation serves to illustrate and elaborate this point.

International taxation, i.e. the tax treatment of cross-border activities such as, most notably, foreign real or financial investment raises two main policy issues: international double taxation and international tax competition. International double taxation refers to the problem that cross-border activity is potentially taxable in more than one jurisdiction and may therefore carry a higher aggregate tax burden than purely domestic activity. International tax competition refers to the problem that cross-border activity can be used to evade or avoid high taxes at home and thus push the tax burden below that of purely domestic activity. Double taxation discourages efficient cross-border investment and results in welfare reducing economic underintegration. Tax competition encourages inefficient cross-border investment and results in welfare-reducing over-integration. As we will show, both issues are interdependent: The approach taken to mitigating the problem of double taxation affects the shape and intensity of tax competition and vice versa.

The TLOs in international taxation have attended to both issues sequentially. In the early decades, roughly the 1920s to the 1960s, the focus was almost entirely on double tax relief. In the short run, this narrow focus facilitated the formation of a TLO with a high level of issue alignment (since the 1950s, the OECD has emerged as the TLO's solid institutional center) and a high degree of normative settlement (the OECD's rules on double tax relief have diffused widely as taken-for-granted guidelines for international taxation). In the long run, this narrow focus had unintended, if not completely unforeseen, consequences for tax competition. First, the TLO on double tax relief inadvertently invigorated tax competition. It opened new options for taxpayers to reduce their tax bills through cross-border tax arbitrage and left national governments free to vie for inbound tax arbitrage flows by aggressive low-tax strategies. Tax competition spread slowly during the 1960s and 1970s and accelerated during the 1980s, 1990s

\footnotetext{
${ }^{1}$ Philipp Genschel, Jacobs University Bremen, p.genschel@jacobs-university.de. Thomas Rixen, University of Bamberg, thomas.rixen@uni-bamberg.de. Thanks to the participants of the Jamaica Workshop for helpful comments and discussions.
} 
and 2000s. Second, the TLO on double tax relief constrained the legal and political opportunity space for curbing tax competition: The normative settlement on double tax relief militated against any legal change undermining this settlement; the rise of tax competition created strong vested interests in tax competition which opposed any TLO change to curb it. Hence, the TLO of double tax relief simultaneously created demand for a TLO solution of the tax competition problem and hindered the supply of such a solution.

This dilemma triggered two types of responses: first, a reinterpretation of the rules of the double tax relief TLO and, second, the creation of a new TLO focused on tax competition. The strategy of reinterpretation aimed at subtly changing the operative meaning of TLO rules on double tax relief so as to limit their abuse for tax arbitrage purposes while at the same time leaving them notionally intact so as to protect the normative settlement around them. This strategy was pioneered by the United States, which introduced unilateral anti-avoidance legislation restricting taxpayer access to double tax relief in the 1960s, promoted the adoption of similar legislation by other states and achieved a formal OECD endorsement of antiavoidance rules in the 1980s. Still, the success of this strategy remained limited both in terms of protecting normative settlement and curbing tax competition. The second strategy - creation of a new TLO - was partly a reaction to this failure. The initiative came from the G-7 which mandated the OECD in 1996 to take action against 'harmful tax competition'. The idea was to limit governments' freedom to abuse domestic tax policy for poaching foreign tax base. The instrument was to be common minimum tax standards. One main problem was whether to exclude the beneficiaries of tax competition (mostly so-called 'tax havens') from negotiations and simply impose minimum standards on them or to include them and persuade them to cooperate voluntarily. In the end, the tax havens were included. They now participate in great numbers in the 'Global Forum on Transparency and Exchange of Information for Tax Purposes', which ensures widespread rule compliance but also limited rule effectiveness in curbing tax competition.

The remainder of the chapter is structured into six parts. In the next part, we introduce the issues of double taxation and tax competition and discuss their interdependence (section 2). Then we reconstruct the formation and institutionalization of the TLO on double tax relief (section 3), and analyze its impact on taxpayers, governments, and tax competition (section 4). In the following sections, we analyze the competition-induced TLO change. First, we focus on TLO change by reinterpreting established rules of double tax relief (section 5). Then we analyze the formation and fragile institutionalization and impact of the new TLO on tax competition (section 6). The final part summarizes the main findings and spells out lessons for the TLO research program (section 7).

\section{The trilemma of international taxation: tax sovereignty, double taxation and tax competition}

International double taxation and international tax competition have a common cause: national tax sovereignty, i.e. the exclusive right of national governments to make tax law (legal sovereignty), to administer and enforce tax law (administrative sovereignty) and to claim all tax revenue for the national budget (revenue sovereignty). Tax sovereignty is a cause of international double taxation because it empowers national governments to decide independently whether and to what extent cross-border activities are liable to domestic tax. The uncoordinated exercise of this power by multiple governments can lead to overlapping tax claims that subject cross-border activities to a higher tax burden than domestic activities. This creates a tax barrier between national jurisdictions that discourages cross-border activities, traps 
economic agents in national markets, and hinders international economic integration. Think, for instance, of foreign investment income that is fully taxed first in the source country of the investment and then in the residence country of the investor (e.g. Avi-Yonah 2006).

National tax sovereignty causes international tax competition because it empowers national governments to undercut the taxes of foreign governments. Taxpayers can exploit the resulting difference in national tax levels for arbitrage purposes: they engage, or threaten to engage, in cross-border activities that shift tax liabilities ('tax base') out towards jurisdictions with lower taxes and thus reduce their tax burden. Such tax arbitrage can take two forms. First, there is (illegal) tax evasion. Think, for instance, of individual investors concealing their foreign investment income in order to evade domestic tax in their country of residence. Second, there is tax arbitrage by (legal) avoidance. Think, for instance, of multinational corporate groups targeting their foreign direct investment at low-tax jurisdictions or structuring their intra-firm but cross-border commercial and financial transactions so as to shift paper-profits to affiliates in low-tax jurisdictions and deductible expenses to affiliates in high-tax jurisdictions (for an accessible overview of basic avoidance techniques, see Arnold and McIntyre 1995, 8-17 and 69-88). Taxpayer arbitrage can, in turn, trigger an interactive spiral of tax cuts by governments trying to attract inflows or prevent outflows of mobile capital. This limits the ability to generate revenue from capital taxation, creates inequities in relation to immobile tax bases, and accelerates international economic integration (Avi-Yonah 2000; Tanzi 1995; Genschel and Schwarz 2013).

Governments cannot solve the twin problems of double taxation and tax competition and preserve national tax sovereignty at the same time. One of the three goals has to give: Governments can mitigate double taxation and preserve national sovereignty largely intact but then have to face increased tax competition; they can mitigate tax competition in a sovereigntypreserving way by pushing up double taxation; or they can solve both problems simultaneously but then have to pool sovereignty at the international level. This is the trilemma of international taxation.

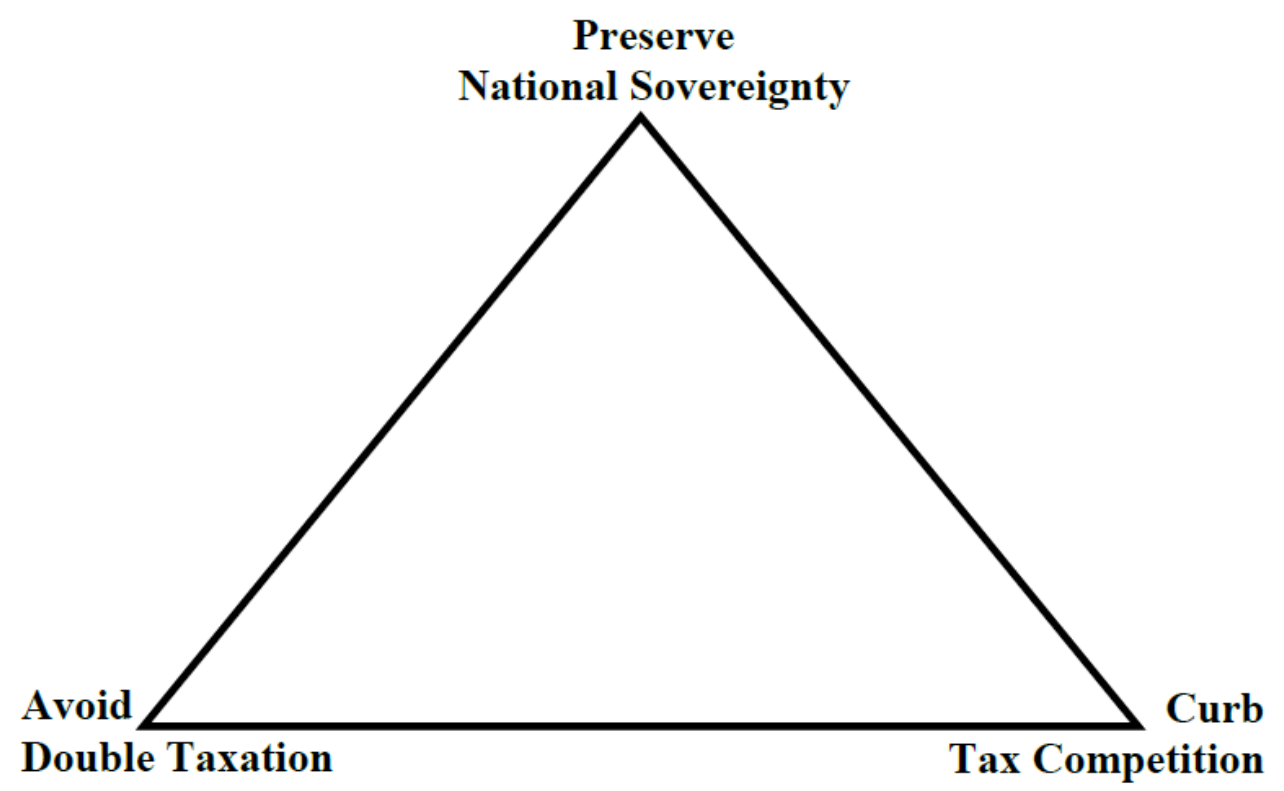

Figure 1: The trilemma of international taxation

The sovereignty-preserving way to relieve double taxation is for governments to cut back their tax claims to cross-border transaction. Whether they do so unilaterally or by bilateral 
or multilateral agreement, the cutback reduces the risk of overlapping claims to the same transaction and thus reduces double taxation. However, it also reduces obstacles to international tax arbitrage. As double taxation decreases, the extra-costs of cross-border transactions decrease as well and the incentives to exploit cross-national differences in tax level increase: The lower the tax barrier between national tax jurisdictions, the higher the probability that taxpayers will engage in cross-border activities to shift tax base into low-tax jurisdictions, and that governments will engage in strategic tax cutting in order to attract inflows - or prevent outflows - of mobile base. Thus double tax relief endogenously breeds tax competition.

The sovereignty-preserving way to curb tax competition is for governments to expand their tax claims to cross-border activities. This will increase the likelihood of double taxation. The tax barriers between national tax jurisdictions go up, which, in turn, decrease incentives for taxpayers to exploit differences in national tax levels by international tax arbitrage, and incentives for government to vie for international tax arbitrage through competitive tax cutting. Thus international double taxation solves the tax competition problem.

The only way to simultaneously mitigate international double taxation and tax competition is to pool tax sovereignty internationally. The pooling may take different forms but always involves a loss of national tax sovereignty. For example, by introducing harmonized minimum tax rates, governments can stop an unmitigated tax race to the bottom but have to give up legal sovereignty for that. By creating an international system of tax information exchange, they can curb tax evasion. Under such a system, the source country informs the residence country about the foreign incomes of its residents and thus makes it risky for taxpayers to conceal such income: National tax authorities render administrative assistance to foreign authorities and, in turn, become dependent on foreign assistance. This requires a sacrifice of administrative sovereignty. Finally, to the extent that legal harmonization or administrative cooperation has redistributive consequences, their political viability may depend on revenue sharing between the governments involved. Think, for instance, of the EU savings tax directive or the pending Swiss-German double tax treaty which both oblige source countries to transfer part of their revenues to residence countries, thus undermining national revenue sovereignty.

\section{The formation and institutionalization of the TLO of double tax relief}

The history of TLOs in international taxation is a history of attempts to balance and rebalance the trilemma of international taxation. The history starts in the early 1920s with negotiations under the auspices of the League of Nation over the creation of a multilateral regime for double tax relief. ${ }^{2}$

Double taxation was not a completely new issue. Even before WW I, taxpayers had occasionally complained about the double taxation of, for instance, cross-border inheritances, and some governments already provided selective and unsystematic relief through unilateral legislation or bilateral double tax treaties(Seligman 1928: 37-57). Three factors ("facilitating circumstances") greatly increased issue salience after WW I. First, the war effort had pushed up tax burdens across the warring states (Steinmo 1993: 50-79), thus making double taxation more costly and burdensome for taxpayers. Second, the war had significantly accelerated a fundamental change in tax structure: The relative importance of taxes on immobile and easy to tax economic assets and activities (tariffs, tolls and real estate duties) declined, while the importance of new taxes on potentially mobile assets and activities such as, most prominently

\footnotetext{
2 This section draws heavily on Rixen 2008: 86-116.
} 
personal or corporate income increased. This made international double taxation more likely (Seligman 1928: 7-16). Finally, the war had undermined the nationalistic justification of double taxation as a protective wall around domestic economic resources, and increased the normative appeal of double tax relief as a means to cultivating international peace by facilitating crossborder trade and investment (Carroll 1939).

In 1919, the newly founded International Chamber of Commerce (ICC) started calling for international cooperation to reduce double taxation. In 1921, the equally new League of Nations commissioned an expert report and launched multilateral negotiations in 1925. The key players in these negotiations were national governments of major industrialized economies (Argentina, Belgium, Czechoslovakia, France, Germany, Italy, Japan, the Netherlands, Poland, Switzerland, the UK, the USA, and Venezuela). The negotiators were technical experts from treasury departments rather than professional diplomats. Private actors such as the ICC participated in an advisory capacity. The negotiations focused almost exclusively on double tax relief. Given the substantial tax barriers between national jurisdictions, tax competition was a non-issue of little practical or political significance. While some negotiators anticipated problems, they refused to address them explicitly before the issue of double taxation was settled (Rixen 2008: 120-122). This facilitated convergence on a sovereignty-preserving approach to providing double tax relief. The idea was to negotiate common rules for disentangling competing national tax claims. The rules would define which part of cross-border activities fall under the tax jurisdiction of which government, and thus eliminate double taxation. At the same time, they would leave governments free to apply whatever tax they liked within their national jurisdiction and thus leave national tax sovereignty largely untrammeled. The rules would assign rights to tax without prescribing whether and how to exercise them: Tax coordination rather than harmonization.

The major issue in the negotiations was the design of the rules: According to what principle should they disentangle competing tax claims? The question triggered considerable debate among the negotiators and in the emerging academic literature on international taxation. Two competing answers emerged which continue to structure international taxation to the present day: the source principle and residence principle. According to the source principle the right to tax cross-border income-flows lies exclusively with the source country, i.e. the country in which these flows originate (the country of employment, investment or business activity). The residence principle, by contrast, assigns the right to tax exclusively to the residence country of the income recipient (the worker, investor, or parent company), i.e. the destination country of cross-border flows. There were arguments in favor of both principles. The source principle was administratively convenient and reflected the legitimate concern of source countries to recover the costs of public goods provided to foreigners doing business in the domestic economy (benefit criterion). The residence principle, by contrast, allowed for progressive income taxation because it assessed taxpayers on their total (worldwide) income rather than just their domestic income. This allowed adjusting the individual tax burden to the individual ability to pay (ability to pay principle). Most important for the negotiations, the source principle benefitted the fiscal interests of capital-importing countries by assigning a larger part of the transnational tax base to them. The residence principle, in turn, benefitted capital-exporters. Largely for this reason, the main cleavage during the negotiations was between the large capitalimporters of Continental Europe (e.g. Italy, France, Germany), which preferred a mostly source-based solution to the problem of double taxation and large capital exporters (the Netherlands, the United States and, most outspoken, the United Kingdom) preferring a more residence-based solution (e.g. Graetz and O'Hearh 1997; Musgrave 2006). 
The cleavage prevented agreement on a single, binding multilateral treaty on double tax relief. Instead the negotiators settled for a non-binding multilateral Model Convention in 1928 that was to serve as a template for binding bilateral double tax avoidance treaties. To further mitigate conflict between capital-importers and exporters, the Convention offered three alternative templates rather than just one, providing different mixes of source- and residencebased elements. All three templates drew on the same basic rules and concepts, however. National governments were free to draw on the Model Convention or ignore it partly or completely (Carroll 1939: 21-25). Hence, the coherence and obligatory character of this initial settlement were rather low. Perhaps surprisingly, from these rather inconspicuous beginnings grew a highly institutionalized TLO with strong issue alignment and normative settlement.

Consider issue alignment first. Two factors helped to increase it over time. First, the unification and consolidation of the Model Convention: In 1928, the League of Nations established a permanent fiscal committee of eight (later nine) country representatives to regularly review the Convention and increase its coherence. Already during the 1930s, this Committee achieved a substantial rapprochement of conflicting positions. After a short stint under the auspices of the United Nations, the OEEC's (later OECD's) Committee on Fiscal Affairs took over from the League's Committee in the 1950s. The first OECD Model Convention published in 1963, consolidated the final compromise between source and residence based double tax relief (van den Tempel 1967). The primary right to tax 'active business income' (i.e. individual wage income and corporate income from productive activity) was assigned to the source country (see art. 7 OECD Model Convention), the primary right to tax 'passive income' (interest, dividends, royalties) to the residence country (see art. 10-12 OECD Model Convention). The Model Convention provided the legal concepts for implementing these assignments and protecting them from foreign incursion. For instance, the concept of 'permanent establishment' (art. 5 OECD Model Convention) was introduced to safeguard source countries' right to tax active business income. The concept constitutes domestic affiliates of foreign companies as taxpayers in their own right ('separate entities') taxable under domestic laws (i.e. the law of the source country). This bars the home country of the foreign parent company (the residence country) from extending its tax jurisdiction to the profits of these subsidiaries. To protect residence countries' right to tax passive income, the model convention proposed caps for the withholding tax that source countries may charge on such income (cf. Rixen 2008: 65-76).

The second factor increasing issue alignment was the failure of all attempts to supplant the OECD Model Convention by competing designs. In the 1970s, the Latin American Free Trade Association (LAFTA) published an alternative Model Convention that was more heavily source-based than the OECD convention. However, it failed to gain currency because OECD countries refused to sign bilateral treaties on this basis. In 1980, the UN published a Model Convention that also aimed to extend the scope for source taxation. This convention did not fail so much as being absorbed into the OECD orbit. Conceptually similar to the OECD Convention, it came to be regarded as a moderate modification of the OECD Model Convention for the special case of treaty negotiations with developing countries rather than a radical alternative. In a sense, the deference of the UN Convention to the OECD Convention buttressed the latter's authority as the uncontested core of the TLO of double tax relief (Vann 2010: 8).

Normative settlement increased in line with issue alignment. Settling occurred at three levels. At the multinational level, the frequency of radical rule change slowed down quickly after the 1930s while the precision of the rules greatly increased. With the first OECD Model Convention of 1963, the fundamental principles and the basic structure of the convention were finally settled. Almost all articles of the current Convention were already present in the 1963 
draft. To increase consistency in application, the OECD published a first comprehensive legal commentary of the Convention on an article-by-article basis in 1963. Continuously updated and refined, the Commentary serves as a key reference for governments, taxpayers and the judiciary. It helps to establish shared interpretations, crystallizes the emergence of a transnational expert community united by the conviction that adoption of the OECD Model is "the solution to international tax problems” (Vann 2010: 6), and increases rule predictability (Picciotto 1992). At the bilateral level, the norms of the OECD Model Convention are embedded in an increasing number of bilateral double tax treaties (DTTs). As figure 1 shows, the number of DTTs remained low into the 1960s but grew rapidly thereafter. While formally free to deviate from the soft law rules of the Model Convention, most governments follow them closely. Almost all of the more than 2000 bilateral DTTs now in existence mirror the Convention's formal structure and content. Finally, settling also occurred at the national level. In addition to reciprocal relief under bilateral tax treaties, most governments also provide unilateral relief under domestic law for cross-border transactions with non-treaty partner countries. While initially not intended for this purpose, the Model Convention also serves as a reference point for this type of law. Most domestic laws of double tax relief broadly follow the principles and concepts of the Model Convention (active v. passive income, permanent establishment, etc.). As a consequence, the OECD Model Convention now represents the general consensus on international taxation; its principles, norms and rules guide bilateral treaty bargaining but also effectively constrain domestic laws countries apply to the taxation of cross-border events. It embodies a broadly accepted, and taken-for-granted practice in international affairs (Avi-Yonah 2006).

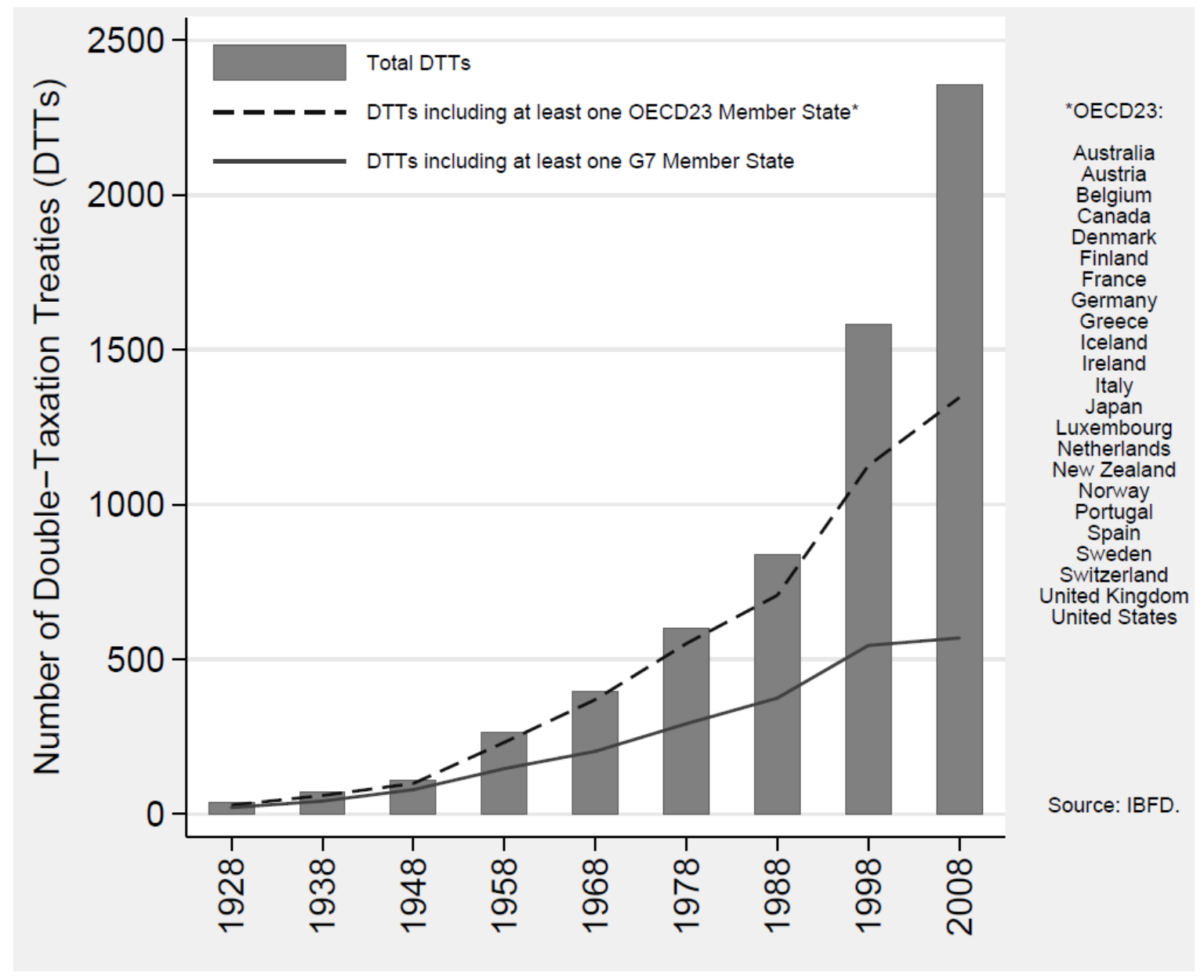


What are the causes behind the secular trend towards institutional entrenchment (i.e. issue alignment and normative settlement)? First, decolonization: The rise of non-Western states mitigated intra-Western conflicts over source v. residence-based double tax relief. With respect to non-Western states all Western states were capital exporters. This facilitated their eventual convergence on the OECD Convention's heavily residence-based rules for taxing cross-border (passive) income flows. Second, power asymmetry: the western countries dominated the world economy. They were the main global suppliers of real, financial and human capital. The rest of the world depended on Western investment more than the West in turn depended on investment from it. This gave Western governments extensive power to dictate the terms under which cross-border flows of investment income are taxed (cf. Surrey 1978a, 1978b). This is indicated by the high share of bilateral tax treaties with OECD-countries in general and G-7 countries in particular (see figure 2). It also explains why the OECD could virtually monopolize work on the Model Convention without undermining the Convention's global acceptance and effectiveness. For if non-Western states refused to settle on the basis of that Convention they did not receive any bilateral tax treaties at all, as illustrated by the sorry fate of the LAFTA Convention. Third, professional closure: the OECD's political preeminence in the area of double tax relief helped to establish it as the preeminent site of technical expertise on this issue. By writing the rules of the game, the technical experts of the Committee on Fiscal Affairs enjoy a natural head start in knowing and interpreting them with authority. The foundations for this authority were laid in the period from the 1930s to the 1960s, when crossborder investment and capital mobility were low and international double taxation a secondary concern of minor political salience. This allowed the experts to craft a compromise solution without major intervention from their political principals. The Committee became the focal point of a transnational expert community of lawyers, administrators and advisers. The OECD Model Convention was embedded in a broad epistemic consensus on 'how to do double tax relief properly', which in turn reinforced its status as the self-evident reference point in matters of double tax relief once cross-border investments and capital mobility started to increase in the 1970s (Picciotto 1992: 35-39). Finally, network externalities: the model convention reduces governments' transaction costs of providing double tax relief by proposing standard ways for disentangling national tax claims. In a way, it supplies common interface standards for the connection points between national tax jurisdictions. As is well known from information technology, the utility of interface standards increases in use (Arthur 1994): as the number of governments using the Model Convention in bilateral treaty bargaining and unilateral tax legislation increases, the incentive to also rely on the Convention in own bargaining and legislation increases. Compliance becomes self-reinforcing.

\section{Unintended impact: tax competition}

Overall, the TLO of double tax relief had "impact" as defined by Halliday and Shaffer (this volume). First, it clearly produced behavioral changes on the national level, which solved the problem for which it had been designed. This impact unfolded slowly until the 1960s and more quickly thereafter as it became increasingly common for governments to provide double tax relief on a unilateral or bilateral basis. The risk of efficient transnational transactions being blocked by national tax barriers decreased significantly. In addition, however, the TLO also had a secondary and unintended impact: it triggered behavioral and structural changes which 
generated a new problem, tax competition, as the trilemma of international taxation would lead us to expect.

Tax competition emerges from the interaction of two types of behavior: taxpayer arbitrage and strategic tax setting by governments. The TLO of double tax relief provides opportunities and incentives for both. Consider tax arbitrage first. The TLO of double tax relief facilitates arbitrage in two ways. First, it lowers the extra (tax) costs of transnational transactions thus making it potentially more profitable for taxpayers to use such transactions for shifting tax base between high and low-tax jurisdictions. Second, less obviously, it equips taxpayers with the essential instruments of arbitrage: By telling governments how to disentangle their tax claims to cross-border transactions, the TLO rules implicitly also tell taxpayers how to structure such transactions in order to move tax base out of reach for high-tax jurisdictions. Thus, all major strategies of corporate tax avoidance play on the Model Convention's rules for the taxation of 'active business income' (Leibrecht and Rixen 2010). Most importantly article 7 stipulating that permanent establishments are taxable as separate entities in their country of operation (source country) allows multinational groups to structure their internal commercial and financial relations such that taxable profits accrue mostly to group-establishments in lowtax jurisdictions and deductible expenses to group-establishments in high-tax jurisdictions. Multinational groups can, for instance, set up subsidiaries in low-tax jurisdictions for the taxprivileged holding of group assets (financial reserves, brands, patents, licenses, technical and managerial know how) - so-called base companies. Base companies can then be used for stripping affiliated companies in high-tax jurisdictions of taxable profits, for example, by charging inflated transfer prices for the use of group assets (transfer price manipulation) or by capitalizing subsidiaries in high-tax locations by debt (thin capitalization). ${ }^{3}$ In either way, the taxable profits of the high-tax subsidiary decrease, the taxable profits of the holding increase, and the after-tax earnings of the group as a whole rise.

Also, the major strategies of tax evasion ${ }^{4}$ are endogenous to the rules of the Model Convention, especially articles 10-13 on the taxation of passive income. Since these articles assign taxing rights primarily to the residence country while capping the taxing rights of the source country, one obvious way for individual investors to reduce their tax bill is to invest abroad and (illegally!) conceal the resulting investment income from tax authorities at home. In this way, they only have to pay the low withholding taxes of the source country - if the source country charges any withholding taxes at all.

As a recent survey of the empirical literature shows, international tax arbitrage is now a major factor in corporate and individual income taxation (Genschel and Schwarz 2011). Corporate foreign direct investment and especially the reported profits (paper-profits) of multinational corporate groups are highly sensitive to cross-national differences in taxation, testifying to high-levels of corporate tax avoidance. Also individual income tax evasion seems to be quite prevalent, especially out of high-tax countries and into tax havens. This exemplifies how TLOs can shift the boundary between market and state(s), as highlighted by Shaffer and Halliday (this volume), in this case in favor of market actors' ability to avoid tax.

\footnotetext{
${ }^{3}$ Since interest is usually deductible against the corporate tax, loans given by the base company to subsidiaries in high-tax jurisdictions will reduce the taxable profits of the latter, swell the profits of the former and, thus, increase after-tax earnings of the corporate group as a whole.

${ }^{4}$ Recall from section 2 that tax evasion is illegal while tax avoidance is not: avoidance exploits loopholes and grey zones in tax law. It is in line with the letter of the law if not necessarily its spirit. Tax evasion, by contrast, breaks the law. In practice the dividing line between the two is often blurred because tax codes are often ambiguous and contain rather general anti-avoidance clauses.
} 
Consider strategic tax setting next: The sovereignty-preserving design of the TLO not only serves as a legal infrastructure for cross-border tax arbitrage, it also leaves governments with ample scope to invigorate tax arbitrage by purposefully undercutting each other's taxes. The focus of this tax competition is on multinational corporations and rich individual investors. The key to luring in mobile corporate investments and profits is to offer corporations a low corporate tax burden either through a low general corporate tax rate or through selected tax advantages ('preferential tax regimes') for specific, presumably very mobile and tax-sensitive, corporate forms and activities (e.g. foreign-held companies, companies in special business zones, or holding or headquarter operations). The TLO of double tax relief allows for both strategies because it completely refrains from harmonizing (effective) tax rates. It also fails to effectively regulate corporate tax arbitrage between different national tax systems. It is completely silent on avoidance instruments such as thin capitalization and foreign base companies. And while it sets the so-called arm's length standard to curb transfer price manipulation, the standard is ineffective at its task. It requires prices in intra-corporate group transactions to be set as if the permanent establishments involved were completely distinct and separate enterprises doing business wholly independently of each other (OECD Model Convention art. 7 (2)). However, the reason why multinational companies exist is that certain cross-border activities are difficult to transact between completely separate enterprises. Hence, there simply is no market price to evaluate objectively if Microsoft's Irish subsidiary charges Microsoft USA inflated royalties and license fees for copyrighted software code initially developed by US software engineers and thereby artificially reduces the American corporate tax base (Sikka 2010).

The key strategies for attracting inward investment by foreign tax evaders are low or no withholding taxes on (passive) investment income (interest and dividends) and generous protection of investor anonymity for instance by strict bank secrecy laws, bearer shares or other instruments purposefully concealing the personal identity of the holder. Again, the OECD Model Convention sets no effective bounds to these strategies. While it proposes maximum rates for source country withholding tax rates on interest and dividends it does not insist on any minimum rates. And while article 26 provides for the mutual exchange of information among tax authorities, it effectively leaves it to each individual government to decide what type of tax information it is willing to collect and exchange.

Various indicators point to the spread of international tax competition. First, there is ample anecdotic evidence of the diffusion of special corporate tax regimes since the 1960s (Ruding Report 1992; Kemmerling \& Seils 2009). Examples such as the Luxembourg or the Dutch Holding Company Regimes, the Belgian Co-ordination Centers or the Dublin Docks are (in)famous. Unfortunately, there is no internationally comparative time-series data. However, a recent count by the OECD suggests that all but four of a sample of 22 advanced Western democracies had at least one special corporate tax regime in 2000 (see table 1). Second, since the mid-1980s there has been a clear and pronounced downward trend in general corporate tax rates in the OECD (table 1) and beyond (Genschel and Schwarz 2011). Third, withholding tax rates on individual investment income (non-resident interest income in table 1) have also generally fallen since the 1980s. Fourth, as corporate and withholding tax rates have fallen, their correlation with country size increased (table 1). This is an important indicator of rising competitive pressure because, as the standard tax competition model from public finance shows, relatively small countries face stronger incentives to cut rates under tax competition than relatively large countries and suffer smaller revenue losses in the competitive equilibrium. Intuitively, this is because for the small country, the revenue loss from a tax cut - i.e. revenue forfeited from the (initially small) domestic tax base - is relatively minor compared to the major 
revenue gain from the inflow of part of the (initially large) foreign tax base of the other country. Hence, the small country faces a more elastic supply of the mobile tax base than its large competitor. In equilibrium, it will undercut the rate of the large country and attract a disproportionately large share of the internationally mobile tax base. Smallness is an advantage under tax competition (Wilson 1999: 278) that explains why tax havens are always small countries. 
Table 1: Indicators of tax competition for 22 OECD countries

\begin{tabular}{|c|c|c|c|c|c|}
\hline & \multirow{2}{*}{$\begin{array}{c}\text { Special Corporate } \\
\text { tax regimes } \\
2000\end{array}$} & \multicolumn{2}{|c|}{ General corporate tax rate } & \multicolumn{2}{|c|}{ Interest Income Non-residents } \\
\hline & & 1985 & 2007 & 1985 & 2007 \\
\hline Australia & 1 & 50 & 30 & $\ldots$ & $\ldots$ \\
\hline Austria & 1 & 61 & 25 & 5 & 0 \\
\hline Belgium & 5 & 45 & 34 & 25 & 15 \\
\hline Canada & 3 & 45 & 36 & 25 & 25 \\
\hline Denmark & 0 & 40 & 25 & 0 & 0 \\
\hline Finland & 1 & 60 & 26 & $\ldots$ & 0 \\
\hline France & 2 & 50 & 34 & 25 & 16 \\
\hline Germany & 2 & 63 & 39 & 0 & 0 \\
\hline Greece & 4 & 44 & 25 & 56,8 & 10 \\
\hline Ireland & 2 & 50 & 13 & 35 & 0 \\
\hline Italy & 2 & 46 & 37 & 21,6 & 27 \\
\hline Japan & 0 & 56 & 40 & 20 & 15 \\
\hline Luxembourg & 3 & 40 & 30 & 0 & 0 \\
\hline Netherlands & 7 & 43 & 33 & 0 & 0 \\
\hline New Zealand & 0 & 45 & 33 & $\ldots$ & $\ldots$ \\
\hline Norway & 1 & 51 & 28 & 0 & $\ldots$ \\
\hline Portugal & 3 & 55 & 26,5 & 13,8 & 20 \\
\hline Spain & 1 & 35 & 33 & 18 & 0 \\
\hline Sweden & 1 & 60 & 28 & 0 & 0 \\
\hline Switzerland & 2 & 35 & 34 & 35 & 15 \\
\hline United Kingdom & 0 & 40 & 30 & 30 & 0 \\
\hline United States & 1 & 50 & 39 & 30 & 30 \\
\hline OECD-22 & 1,95 & 48,4 & 29,7 & 17,91 & 9,11 \\
\hline $\begin{array}{l}\text { Correlation with } \\
\text { country size }^{a)}\end{array}$ & $-0,16$ & 0,16 & 0,63 & 0,25 & 0,49 \\
\hline
\end{tabular}

Notes: a) correlations are with the population logarithm. Data: adapted from Genschel \& Schwarz 2013 
The global rise of tax havens is the final indicator of the spread of tax competition. Tax havens are jurisdictions with very low or zero corporate and withholding tax rates or other tax attributes designed to attract foreign investors such as preferential corporate tax regimes and extensive secrecy legislation. Tax havens are not a completely new phenomenon but their number and importance rose steeply after the 1960s. Depending on the classificatory scheme used, there are now between 40 and 72 tax havens world-wide. These havens have attracted an increasing share of the globally mobile corporate and capital tax base since the 1980s. Allegedly, more than half of global cross-border lending and about 30 percent of Foreign Direct Investments pass through them (Palan et al. 2010). As a consequence, tax havens have undergone rapid economic growth over the past 25 years and are now considerably more affluent than other countries (Hines 2005).

In the introduction to this volume, Halliday and Shaffer conjecture that one way in which TLOs produce impact is by changing how nation-states have impact on each other. The TLO of double tax avoidance is an example of this: It creates a structure that enables nationstates to exert competitive pressure on other governments and thus change their tax policies. Was this effect anticipated by the actors involved?

The trilemma of international taxation makes it look obvious that a sovereigntypreserving TLO of double tax relief must trigger tax competition (see figure 1 above). Why didn't the tax experts and government officials anticipate this outcome when negotiating the TLO in the 1920s and 1930s? As shown elsewhere (Rixen 2011: 210-212), they did indeed foresee an invigoration of tax avoidance and evasion and introduced (very limited) antiavoidance rules into the Model Convention to prevent it. These rules include the arms-length standard for transfer pricing and the information exchange provisions (Art. 26) mentioned above. But, for one, they did not anticipate the actual magnitude of future cross-border arbitrage flows. Also, more importantly, they gave priority to solving the problem of double taxation. In fact, it was agreed that addressing issues of international tax evasion and avoidance should be conditional on successful double tax avoidance, which was the prevalent issue at the time. This only began to change from the 1960s onwards, the period to which we turn now.

\section{Resilience and re-interpretation}

As the previous section has shown, the very success of the TLO of double tax relief helped to create a new problem: tax competition. The repercussions were felt most intensely by the TLO's founders and promoters: the large, economically-advanced states of the OECD area. They lost tax autonomy and tax base to each other and, perhaps even more importantly, to tax havens inside the OECD such as Switzerland, Ireland and Luxembourg and outside the OECD such as Liechtenstein, the Cayman Islands, the Netherlands Antilles or Hong Kong. Yet these repercussions failed to undermine the TLO. Rather than withdrawing support from it, the major Western states premised all strategies for curbing tax competition on its preservation. Why did they do so? What explains the resilience of the TLO of double tax relief?

One reason is sunk costs: the very success of the TLO in generating a large installed base of bilateral tax treaties and domestic tax laws incorporating elements of the OECD Convention militates against change. Ever more treaties have to be re-negotiated, more domestic laws reformed, extensive case law overturned, and text books re-written. All this is difficult and costly. In a sense, therefore, the TLO's high level of normative settlement made it resistant to change (cf. Vann 1991, 100). A second reason is closely related: the lack of a plausible alternative on which governments could easily coordinate. Giving up on the OECD framework of double tax relief would not only imply a major write-off of sunk costs, but also 
cause considerable uncertainty whether a better arrangement would emerge. Third, the TLO's inbuilt distributive bias continues to benefit major OECD member states. While these states may be suffering from tax competition with tax havens, they benefit from the Model Convention's residence-based rules on passive income in relation with non-tax haven states. Since most states continue to be non-havens, and since many of these non-havens heavily import Western capital and technical know-how, Western states' have a vested interest in preserving the TLO. Fourthly, and closely related, Western states have an interest in interest in preserving the OECD as the single and uncontested center of the TLO because this locks in their disproportionate influence over the contents of the TLO rules. As Figure 2 shows, the share of DTTs involving at least one OECD treaty partner declined from roughly 85 percent in 1988 to just about 57 percent in 2008. DTTs are no longer an exclusive preserve of OECD countries. Yet non-Western countries continue to play a marginal role in the OECD Committee on Fiscal Affairs. While experts from a few large non-OECD countries (Argentina, Chile, China, India, Russia and South Africa) participate as regular observers, they do so on the committee's terms. This allows the OECD states to socialize rising non-Western powers into their way of doing double tax relief: privileged control of a TLO of high issue alignment is an asset not easily given up. Finally, the problem of tax competition developed incrementally over many decades. During the 1960s, it was a minor nuisance that did not warrant major TLO change. By the time, it had evolved into a major problem in the 1990s and 2000s it had also undermined important prerequisites for major TLO change as we will see in section 6 below.

The search for TLO-compatible solutions to the tax competition problem went through two stages. The first stage from roughly the 1960s to the 1990s focused on the reinterpretation of central concepts of the TLO so as to reduce their scope for tax arbitrage. The second stage starting in the late 1990s focused on establishing a new TLO. This TLO was intended to operate alongside the old TLO on double tax relief and focus specifically on tax competition.

The process of TLO change by reinterpretation was started by the United States (for the following see Rixen 2008: 120-131). In the 1960s, the US began introducing comprehensive unilateral anti-avoidance legislation with the aim to hinder US companies from using foreign subsidiaries for avoiding US tax. For this purpose it regulated the scope of arbitrage instruments such as transfer pricing, thin capitalization and base companies in tax havens (so-called Controlled Foreign Companies, CFCs). The legislation was contested domestically because it threatened to put US companies at a disadvantage vis-à-vis foreign competitors. While most competitors also came from high-tax OECD countries, they arguably enjoyed a competitive advantage as long as their home countries allowed them to divert profits to tax havens and thus reduce their overall tax bill. In order to mitigate this disadvantage, the US government actively lobbied foreign governments to adopt similar anti-avoidance legislation.

The legislation was also contested internationally because it contradicted central tenets of the OECD Model Convention. Take CFC legislation as an example: It reduces the incentive for US companies to create CFCs in tax havens by taxing US Companies on (parts of) the CFCs' income. In other words, it consolidated the profits of US companies and their tax haven establishments for US tax purposes. This consolidation approach is rather different from the Model Convention's separate entities approach under which different establishments belonging to the same multinational group are taxed separately each in its country of incorporation and operation (source country): The separate entities approach empowers the source country to decide how, if at all, to tax permanent establishments (including CFCs); the consolidation approach empowers the residence country of the parent company to include part of the foreign establishments' (passive) income in the parent's taxable income. The contradiction is easily explained in terms of the trilemma of international taxation. The Model Convention's separate 
entities approach aims to relieve international double taxation and for this purpose risks to facilitate international tax arbitrage while the consolidation approach of domestic CFC legislation aims to mitigate international tax arbitrage at the risk of causing international double taxation. ${ }^{5}$

The unilateral introduction of anti-avoidance legislation spurred conflict in the OECD Committee on Fiscal Affairs. Many experts regarded it as a violation of established TLO rules of double tax relief. In their view, governments had to explicitly reserve the right to use such legislation in their bilateral tax treaties in order to meet their treaty obligations. The principled opposition of the experts was eventually worn down by powerful lobbying of the United States government and the diffusion of anti-avoidance legislation among other major OECD countries. In 1987, the OECD formally endorsed unilateral avoidance measures and encouraged OECD member states to adopt them. While a 1989 report still insisted that these measures required a renegotiation of bilateral treaties, the 1992 Commentary on the Model Convention already noted that a "wide majority" of member states supported the view that anti-avoidance rules "do not have to be confirmed in the text of the convention to be applicable". In 2005, the Commentary finally simply stated that CFC legislation "is not contrary to the provisions of the Convention” (cited in Rixen 2008: 124). The Convention's rules of double tax relief remained unchanged. But their operative meaning was changed by complementing them with new antiavoidance legislation that restricted taxpayer access to these rules. In other words, national antiavoidance legislation was absorbed into the TLO of double tax relief by creatively reinterpreting the TLO's basic rules and concepts. Thus, for instance, complaints by tax havens that CFC laws infringed on their sovereign right to tax business income at source were countered by the OECD and its main member states with the notion of the "deemed dividend". According to this notion, the income of CFCs does not constitute active business income taxable at source but passive (dividend) income to be taxed at the hands of the CFC's shareholder in its country of residence. In this slightly contorted reading CFC rules neither interfere with a tax haven's tax sovereignty nor do they constitute double taxation because passive income rightfully belongs to the residence country anyways (Rixen 2011: 214).

The combination of a stout rhetorical defense of the traditional sovereignty-preserving concepts of double tax relief (permanent establishments, separate entities approach, arm's length standard etc.) at the multilateral level and the adoption of incompatible anti-avoidance policies at the domestic level was intended to protect the normative settlement of the former and reign in tax competition both at the same time. Unsurprisingly, it failed in both regards.

On the one hand, TLO change by reinterpretation failed to protect the normative settlement of the TLO rules of double tax relief. While the basic rules of the OECD Convention remained formally unchanged, they lost their coherence and clarity by being meshed together with anti-avoidance laws, which effectively contradicted them. The rules no longer mean what ostensibly they say. This creates legal uncertainty, increases discretion in rule application and reintroduces the risk of unrelieved international double taxation (Vann 2010). The new antiavoidance rules remain politically contested. Despite OECD endorsement, they lack the 'takenfor-grantedness' enjoyed by the established concepts of double tax relief. As a recent survey shows, the international diffusion of anti-avoidance legislation is selective and incomplete. Of a sample of 32 OECD and CEEC countries, only 18 have CFC or Thin Capitalization rules in place (Genschel and Schwarz 2011: 360). The propensity to adopt such rules is positively and significantly associated with country size suggesting that positional interest in international tax

${ }^{5}$ The arm's length principle underwent a very similar reinterpretation (Rixen 2008: 126-130). 
competition rather than normative conviction drives the adoption process. The extent of normative settlement remains low.

On the other hand, the TLO adjustment by reinterpretation failed to effectively curb tax competition. Various factors contributed to this. Partly it is due to the limited geographical spread of unilateral anti-avoidance legislation we just noted. Partly it is due to the rat race that started between governments devising ever more sophisticated anti-avoidance laws and corporate taxpayers reacting by ever more sophisticated avoidance strategies to circumvent these laws: legal complexity increases, taxpayer compliance costs increase but the constraining effect on arbitrage behavior remains moderate. Even more importantly, anti-avoidance laws failed to address the root cause of international tax arbitrage: the existence of tax rate differentials between countries incentivizing corporate profit shifting. Every government remained free to set its rates as low as it wanted. Finally, the TLO adjustment by reinterpretation failed to address the issue of cross-border tax evasion of individuals. The problem in tax evasion is not that taxpayers use rights they enjoy under the TLO of double tax relief to artificially shift tax base into low-tax jurisdictions. The problem is that they break TLO rules: they conceal foreign income that, according to the rules, they should declare in their country of residence. Reinterpreting the rules does not remedy this problem. What is required is effective crossborder information exchange. Obviously, however, tax havens making a living of attracting foreign tax evaders have neither the incentive to engage in effective information exchange, nor, as we have seen, does the OECD Model Convention force them to.

\section{A new TLO to curb tax competition?}

The 1996 G-7 Summit in Lyon called upon the OECD to establish a multilateral approach to tackle the issue of "harmful tax competition" (OECD 1998). This marked a radical departure from the reinterpretation approach discussed in the former section in two respects. First, it aimed to create a new TLO specifically for the problem of tax competition rather than deal with it under the aegis of the old TLO of double tax relief. Second, it focused on the root cause of tax competition: national tax sovereignty. The new TLO should curb tax competition by constraining national freedom to engage in aggressive tax poaching strategies. There was also an important element of continuity though: the institutional responsibility for the new TLO should rest with the OECD Committee on Fiscal Affairs.

The OECD project on harmful tax competition succeeded in its first aim: There is now a specific TLO dealing with a limited subset of tax competition-related issues, all of them having to do with transparency and information exchange in tax matters. The project largely gave up on its second aim: the pretension of setting common limits to national tax sovereignty was mostly dispensed with in 2001. Instead the new TLO mimics central elements of the sovereignty-preserving set-up of the old TLO. There is now a non-binding Model Agreement on 'Exchange of Information on Tax Matters' that serves as a template for a quickly rising number of bilateral Tax Information Exchange Agreements (TIEAs). Finally, there is less institutional continuity than initially anticipated. Responsibility for the new TLO on information exchange has progressively migrated out of the OECD arena and into a new 'Global Forum on Transparency and Exchange of Information for tax purposes'. While set up under the auspices of the OECD Committee on Fiscal Affairs, the Global Forum is increasingly independent of it and operates as an international organization in its own right. With 105 member states from all over the world, it is much more inclusive than the OECD Committee.

A number of facilitating circumstances precipitated the creation of the new TLO on harmful tax competition. First, governments began to realize in the 1990s that TLO adjustment 
by reinterpretation was not enough to solve the tax competition problem effectively. A more radical approach seemed required (Owens 1998: 231). Second, the EU Single Market Project raised fears of rampant intra-EU tax competition especially as regards preferential corporate tax regimes (Ruding Report 1992). The EU reacted by countermeasures like the Code of Conduct for business taxation and the Savings Tax Directive, and lobbied in the OECD for shoring up these measures by parallel OECD action (cf. Kudrle and Eden 2003: 46-47). Third, the Clinton administration saw clear links between money laundering, criminality and tax evasion and strongly favored multilateral efforts to curb all three forms of abuse (Palan et al. 2010: 210). Finally, the creation of the new tax competition TLO was facilitated by the dominance of leftof-Center governments in EU member states and the US. These governments were united in their sensitivity to issues of corporate and capital tax avoidance and arbitrage, and in their openness to multilateral approaches to dealing with common problems.

The OECD Committee on Fiscal Affairs was charged to investigate the issue and in 1998 published a report on how to tackle it (OECD 1998). The report focused on low levels of taxation as the root cause of tax competition - "The absence of tax or a low effective tax rate on the relevant income is the starting point of any evaluation” (OECD 1998: 21) - but refrained from proposing harmonized common minimum rates. Instead it limited its ambition to reigning in two particularly "harmful" uses of low tax rates that served mainly or exclusively for "poaching" mobile tax base "rightly" belonging to foreign countries (OECD 1998: 16). One such harmful practice was the creation of tax havens. Tax havens are jurisdictions that have no or low general corporate tax rates, and accept profits from "insubstantial" activities (such as letter box companies, booking centers, and similar sham operations) as active business income taxable under these rates. The other harmful practice were preferential tax regimes offering low rates of tax exclusively to foreign investors in defiance of much higher general levels of domestic tax applicable to residents ('ring fencing' of low tax so as to positively discriminate outsiders). The harmful effects of both types of aggressive low tax policies were confounded, in the view of the Committee, by a general lack of transparency and a general unwillingness to exchange information with foreign tax authorities (OECD 1998: 28-30).

The distinction between tax havens and preferential tax regimes had an institutional and a political logic. Institutionally, the implicit understanding was that preferential tax regimes were the primary form of harmful tax competition inside the OECD and therefore could be addressed by the standard OECD procedures of common standard setting, self-reporting and peer review among the member states. Tax havens, by contrast, were mostly non-OECD jurisdictions and had to be addressed differently. Politically, the assumption was that tax havens have a vital stake in tax competition and therefore cannot be relied upon to cooperate voluntarily in curbing harmful tax practices while countries with preferential tax regimes have a stake in protecting their regularly taxed domestic tax base from foreign tax poaching and therefore have much stronger incentives to cooperate (OECD 1998: 21-22 and 27-28).

The curbing of preferential tax regimes largely followed this logic. In 1998, the OECD set up a 'Forum on Harmful Tax Practices' under the aegis of the Committee on Fiscal Affairs to coordinate the work. The member states reviewed existing tax law in light of the OECD report's criteria and, in 2000, published a list of tax havens and potentially harmful preferential tax regimes (OECD 2000). They then went through various rounds of review in order to delete those regimes from the list that were not considered harmful and abolish or amend those that were. In 2006, the problem was officially declared solved: "this part of the project has fully achieved its initial aims and ... the mandate given by the Council on dealing with harmful preferential tax regimes in Member Countries has therefore been met” (OECD 2006: 6). 
Two factors facilitated this notional success. First, the criteria of harmfulness were handled rather laxly. This allowed whitewashing many preferential regimes as not harmful and amending others so as to circumvent the OECD's formal criteria of harmfulness. Some observers conclude, therefore, that the impact of the OECD project on preferential regimes was very low (Palan et al. 2010: 214). This may not be completely fair because some preferential tax regimes were in fact abolished. A second factor contributed to that: the soft law OECD peer review process proceeded in the shadow of hard law investigations in other TLOs. On the one hand, the European Commission scrutinized the preferential tax regimes of EU member states under the state aid rules of the EC Treaty and opened 15 official infringement procedures in 2001. This sent a clear signal to EU member states that their regimes were at risk (Radaelli and Kraemer 2008: 327). On the other hand, some regimes on the OECD list such as the US Foreign Sales Corporation were subject to dispute settlement procedures in the WTO. Hence, the OECD project may not have been completely inconsequential. Ireland, for instance, abolished all preferential regimes incriminated by the OECD. At the same time, however, it slashed its general corporate tax rate from 32 percent in 1998 to 12.5 percent in 2003. Hence, to the extent that the OECD's fight against preferential tax regimes was successful it tended to increase competitive pressures on general tax rates (cf. Keen 2001).

The curbing of tax havens turned out to be much more difficult. The OECD blacklist of 2000 called upon tax havens to remove the harmful features of their tax systems. All tax havens refusing to do so would be regarded as "uncooperative jurisdictions" and would have to face coordinated “defensive measures" by OECD countries (OECD 2000: 19-20). Predictably, tax havens reacted with outrage, protesting the OECD's neo-imperial assault on their tax sovereignty. Nevertheless, they signaled willingness to enter negotiations and reach an agreement with OECD countries. This made it difficult for the OECD to continue its exclusionary, confrontational approach to dealing with tax havens. Also, there were OECDinternal problems. First, the key criterion for identifying tax haven operations, the lack of 'substantial activity', was diffuse. "For example, financial and management services may in certain circumstances involve substantial activities. However, certain services provided by "paper companies" may be readily found to lack substance” (OECD 1998: 24). Any attempt to operationalize the criterion would have been contested among the OECD member states and would have involved the OECD in in-depth investigations of the tax havens (Kudrle 2005 (Kudrle 2005: 21). Second, with the coming to power of the new Bush administration in 2001, the United States defected from the OECD project. Partly, this was due to its instinctive dislike of multilateral approaches. Partly it was due to the suspicion that the project simply served hightax European welfare states to impose their tax views on the rest of the world; a view that was forcefully formulated and effectively brought to the attention of US policy makers by wellorganized business interest groups (Cloud 2001). Therefore the US pushed the OECD to curtail the project to the one aspect it was interested in: transparency and information exchange (Webb 2004) - an interest that greatly gained in salience after 9/11.

As a consequence of these developments, the OECD project was set on a new course substantively and procedurally. Substantively, the initial aim of pressuring tax havens to adapt their domestic tax systems in terms of minimum tax rates or common tax base definitions was off the agenda. Tax havens retain the legal sovereignty to set taxes as low as they want. The substantial activity criterion was dropped from the list of criteria of tax haven status (OECD 2001: 10). The project's new focus was on forcing tax havens to share tax information and render administrative assistance across the border. Of course, this also implied a loss of sovereignty. As the trilemma of international taxation suggests, there is no way to curb tax competition and retain double tax relief without any sacrifice of sovereignty. But this time the 
sacrifice concerned administrative sovereignty only: the aim was to deny tax havens the freedom to protect individual tax evaders from investigations by their home states. The entire complex of corporate tax avoidance dropped out of the picture.

Procedurally, the entire approach became more inclusive and consensual. A 'Global Forum on Taxation' was set up in 2001 under the auspices of the OECD Committee on Fiscal Affairs to bring together OECD member states and offshore tax havens. The Global Forum engaged in developing criteria for the transparency of national tax systems and for the effective cross-border exchange of tax information. In the course of this work, the Forum developed a Model Agreement on Information Exchange (OECD 2002) that serves as a template for bilateral tax information exchange agreements in those cases where governments do not wish to enter into full-fledged bilateral double tax avoidance treaties. The Model Agreement imposed stricter informational obligations on governments than the old article 26 of the OECD Model Tax Convention used to do. In fact, it led to a revision of that article. Still the level of obligation is rather low. Most importantly, the Model Agreement provides only for information exchange upon request, not the automatic exchange of information. This limits effectiveness considerably, as the requesting state has to present initial evidence of evasion: it has to know the information in order to officially request it (Sullivan 2007). The Forum also started a process of peer-review in which the members of the Forum scrutinize each other's legal and administrative frameworks for information exchange (see e.g. OECD 2009).

The work of the Forum received a boost after the Financial Crisis of $2008 \mathrm{ff}$. In contrast to corporate tax competition that arguably was a facilitating factor in the unfolding of this crisis (Keen et al. 2010), the problem of tax evasion and lack of information exchange was not. Still, in a kind of political displacement activity, the G-20 called upon the Global Forum to step up its work (Rixen 2013; for a selection of fiery quotes see Global Forum 2011a: Annex III). As a consequence of this, the Global Forum was reconstituted as the 'Global Forum on Transparency and Exchange of Information for Tax Purposes' and was set up as an independent international organization even if still hosted by the OECD.

What is the impact of the new TLO on harmful tax competition? It is easy to find fault with the work of the Global Forum. It brackets the huge area of corporate tax avoidance that arguably is the most important one. And even in its area of application, individual tax evasion, it is unclear how effective it is. To be sure, it has tightened informational standards and reduced certain barriers to cross-border administrative cooperation. The peer-review of legal and administrative practices of information collection and exchange show spectacular compliance with the Forum's rules (cf. e.g. Global Forum 2011b). The network of bilateral tax information exchange agreements is exploding. The network is far from complete though and certain network links seem rather irrelevant. It is not entirely clear, for instance, to what extent Monaco's bilateral information exchange agreements with Andorra, the Bahamas, Greenland, Liechtenstein, Luxembourg, Iceland, Qatar, Saint Kitts \& Nevis, San Marino, and the Seychelles will contribute to reigning in global tax evasion? A recent empirical study concluded that that "most tax evaders did not respond to the treaties but that a minority responded by transferring their deposits to havens not covered by a treaty" (Johannesen and Zucman 2012). In short, the activities of the Global Forum caused a modest relocation of deposits between havens but no significant repatriation of funds. Arguably the main reason for this lack of impact lies in the shortcomings of information exchange on request. An automatic exchange of taxpayer information would potentially be more effective in curbing international tax evasion.

And indeed, in recent developments a group of countries, pressured by the USA have signalled their willingness to engage in automatic information exchange. The United States government had unilaterally implemented the so-called Foreign Account Taxpayer Compliance 
Act (FATCA) requiring foreign banks to provide information on the accounts of American citizens to the US government. Subsequently, several countries including Germany, France, Italy, Spain, the United Kingdom but also Switzerland, Austria and Luxembourg entered into negotiations with the US government because they did not want their banks to directly provide information to a foreign government. In consequence information is now automatically exchanged via these governments and the USA. It is conceivable that these developments - and current attempts to extend automatic information exchange within the EU savings tax directive - will lead to improvements in the OECD standard of information exchange (for details on this development, cf. e.g. Grinberg 2012). But it is too early to come to definite conclusions on this issue.

In another very recent development, the United Kingdom and Germany, fuelled by tax scandals that received wide public attention (e.g. Starbucks and Apple), have brought the issue of corporate tax avoidance back on the agenda of the G-20 and the OECD. In response, the OECD has initiated a new project on "base erosion and profit shifting" (OECD 2013a,b). While the OECD forcefully stresses the need for action, the concrete measures remain within the mode of reinterpretation, which proved futile in the past. While it remains to be seen, whether the stronger rhetoric signals a more profound change for the future of corporate taxation, so far the framework of sovereignty-preserving cooperation remains intact.

\section{Lessons for the TLO project}

What can we learn from the tax case about the key question of this volume: "how do transnational legal orders (TLOs) originate, consolidate and constrain behaviors in spheres of social life" (Halliday and Shaffer this volume: 2)? We see four potential lessons. The first concerns the origins of TLOs. The initial creation of the Tax TLO was greatly facilitated by its narrow substantive scope. The negotiations focused almost exclusively on international rules for double tax relief and bracketed other problems of international taxation including tax avoidance and evasion. This was not for sheer ignorance. Most negotiators were aware of these other problems and possible links to the issue of double taxation. Yet including these problems would have greatly complicated the negotiations and delayed the establishment of the TLO perhaps ad infinitum. Starting small was the precondition for starting a TLO at all. As we surmise, this is often the case in TLO creation. They do not initially cover an entire "sphere of life" but only subsections of it. Their substantive and perhaps also geographical scope is narrow and selective rather than broad and encompassing. The short-run implication is high initial issue alignment: there is a close "one-to-one correspondence" between the TLO and a particular issue or of set of issues. The long-run implication is that the high initial issue alignment carries the seeds of its own undoing. Precisely because the TLO initially deals only with one particular issue or set of issues in isolation, it is likely to create unintended (if not necessarily completely unforeseen) spill-over effects on other issues: By ordering - solving - one particular problem, they reshape the problem-context and may thus trigger a further round of legal ordering. We come back to this point below.

Our second lesson concerns the consolidation of TLOs. The Tax TLO consolidated at a time, roughly the 1920s to the 1960s, when its practical significance and political salience were rather limited. The volume of cross-border movements of goods, services and factors of production was low. International double taxation was largely a non-issue for policy makers. This gave the small expert community of lawyers and public officials who cared for double tax relief for professional reasons, the freedom to sort out norms and principles in de-politicized 
negotiations with little or no political oversight. This greatly facilitated normative settlement and the emergence of a transnational "epistemic community" embodying it. The normative settlement constrained governments once the issue of double taxation gained in practical importance and political salience from the 1960s onwards: The governments of the global south would have preferred a more source-based order of double tax relief while the United States and some other Northern governments would have preferred an order that is less susceptible to tax avoidance and evasion. But the normatively settled TLO rules on double tax relief were resilient to these challenges. The basic structure and concept of the OECD Model Convention is still the same as in the 1960s. These observations suggest that the de-politicization and professionalization of TLOs is conducive to their consolidation. Political contestation and high politics, by contrast, are likely to block or delay normative settlement.

The third lesson concerns the impact of TLOs. As the tax case shows, TLOs shape social relations and outcomes both by constraining and by enabling behavior. The primary purpose of TLOs is, of course, to constrain behavior in order to solve a given problem: The OECD Model Convention constrains how governments treat cross-border capital flows for tax purposes and thus solves the problem of international double taxation. As a byproduct of the constraints they impose, TLOs often enable new patterns of behavior that, in turn, may lead to follow-on problems and new initiatives for transnational legal ordering. Thus the implementation of the OECD Model Convention in bilateral DTTs and domestic tax laws created new opportunities for cross-border tax evasion and avoidance, and new incentives for governments to engage in strategic tax setting in order to attract inward, and deter outward, evasion and avoidance flows. In this way, the solution of the old problem of double taxation spilled over into the new problem of tax competition. We conclude that TLOs have an inbuilt tendency towards issue expansion, overlap and enmeshment. They often start small with close issue alignment but then tend to expand into adjacent issue areas, creating overlap with other already existing TLOs or with newly established TLOs. As a consequence, the initial issue alignment - if there ever was issue alignment - erodes. While the OECD is still the focal organization in the international tax field, the field is increasingly crowded by new creations such as the Global Forum and new entrants such as the G-7, the G-20 or the WTO. What used to be a single TLO is now better described as a TLO-complex (on the related concept of a regime complex, see e.g. Keohane and Victor 2011).

Finally, because TLOs tend to create unintended follow-on problems and constrain the means for coping with them, timing and sequence matter in TLO-development. It matters how the initial problem is framed that triggers the creation of a TLO and how it is ordered because this will shape the TLO's intended and unintended impact on behavior, and hence what problems and solutions for transnational legal ordering further down the line. 


\section{References}

Arnold, Brian J., and Michael J. McIntyre. 1995. International Tax Primer. Den Haag: Kluwer Law International.

Arthur, W. Brian. 1994. Increasing Returns and Path Dependence in the Economy. Ann Arbor: University of Michigan Press.

Avi-Yonah, Reuven S. 2000. "Globalization, Tax Competition, and the Fiscal Crisis of the Welfare State." Harvard Law Review 113 (7):1573-676.

- 2006. International Tax as International Law: An Analysis of the International Tax Regime. New York: Cambridge University Press.

Carroll, Mitchell B. 1939. Prevention of International Double Taxation and Fiscal Evasion. Two Decades of Progress under the League of Nations. Geneva: Series of League of Nations Publications II. Economic and Financial 1939.II.A.8.

Cloud, David S. 2001. "Virginian Fights for International Tax Havens--Lobbyist Finds Bush Receptive to Ideas Clinton Rejected." The Wall Street Journal, 30 July, A20.

Genschel, Philipp, and Peter Schwarz. 2011. "Tax competition: a literature review." SocioEconomic Review 9 (2):339-70.

Genschel, Philipp, and Peter Schwarz. 2013. “Tax Competition and Fiscal Democracy.” In Politics in the Age of Austerity, eds. A. Schäfer and W. Streeck. Cambridge: Polity Press.

Global Forum (Global Forum on Transparency and Exchange of Information for Tax Purposes). 2011a. Information Brief 15 December 2011. Paris: OECD.

Global Forum (Global Forum on Transparency and Exchange of Information for Tax Purposes). 2011b. Tax Transparency 2011: Report on Progress: http://www.oecd.org/dataoecd/52/35/48981620.pdf (last accessed 31 May 2012).

Grinberg, Itai. 2012. "Beyond FATCA: An Evolutionary Moment for the International Tax System.” Georgetown Working Paper. http://ssrn.com/abstract=1996752

Graetz, Michael J., and Michael M. O'Hearh. 1997. "The 'Original Intent' of US International Taxation." Duke Law Journal 46 (5):1021-109.

Hines, James R. 2005. "Do Tax Havens Flourish?" In Tax Policy and the Economy, Volume 19, ed. J. M. Poterba. Cambridge: MIT Press.

Johannesen, Niels, and Gabriel Zucman. 2012. "The End of Bank Secrecy? An Evaluation of the G20 Tax Haven Crackdown." In Paris School of Economics. Working Paper 2012- 
04. http://halshs.archives-ouvertes.fr/docs/00/66/50/54/PDF/wp201204.pdf (last accessed 31 May 2012).

Kemmerling, Achim, and Eric Seils. 2009. “The regulation of redistribution: Managing conflict in corporate tax competition.” West European Politics 32 (4): 756-73.

Keen, Michael. 2001. "Preferential Regimes can make Tax Competition Less Harmful." National Tax Journal 54 (4):757-62.

Keen, Michael, Alexander Klemm, and Victoria Perry. 2010. "Tax and the Crisis.” Fiscal Studies 31 (1): 43-79.

Keohane, Robert O., and David G. Victor. 2011. "The Regime Complex for Climate Change." Perspectives on Politics 9 (1):7-23.

Kudrle, Robert T. 2005. "U.S. Defection from the OECD “Harmful Tax Competition” Project: Rhetoric and Reality." Unpublished Manuscript.

Kudrle, Robert T., and Lorraine Eden. 2003. "The Campaign Against Tax Havens: Will it Last? Will it Work?" Stanford Journal of Law, Business and Finance 9:37-68.

Leibrecht, Markus, and Thomas Rixen. 2010. "Double Tax Avoidance and Tax Competition for Mobile Capital." In International Tax Coordination. An Interdisciplinary Perspective on Virtues and Pitfalls, ed. M. Zagler. London and New York: Routledge.

Musgrave, Peggy B. 2006. "Combining Fiscal Sovereignty and Coordination. National Taxation in a Globalizing World." In The New Public Finance. Responding to Global Challenges, ed. I. Kaul and P. Conceicao. Oxford: Oxford University Press.

OECD. 1998. Harmful Tax Competition. An Emerging Global Issue. Paris: OECD. 2000. Towards Global Tax Co-operation: Report to the 2000 Ministerial Council Meeting and Recommendations by the Committee on Fiscal Affairs: Progress in 
Identifying and Eliminating Harmful Tax Practices. Paris: http://www.oecd.org/dataoecd/9/61/2090192.pdf (last accessed 31 January 2011).

2002. Agreement on Exchange of Information on Tax Matters. Paris: http://www.oecd.org/dataoecd/15/43/2082215.pdf (last accessed 31 January 2011). 2006. Tax Co-operation. Towards a Level Playing Field. Paris: OECD.

. 2009. Tax Co-operation. Towards a Level Playing Field. 2009 Assessment by the Global Forum on Transparency and Exchange of Information. Paris: OECD.

—. 2013a. Addressing Base Erosion and Profit Shifting. Paris: OECD. . 2013b. Action Plan on Base Erosion and Profit Shifting. Paris: OECD.

Owens, Jeffrey. 1998. "Curbing Harmful Tax Competition - Recommendations by the Committee on Fiscal Affairs." Intertax 26 (8-9):230-4.

Palan, Ronen, Richard Murphy, and Christian Chavagneux. 2010. Tax Havens. How Globalization Really Works. Ithaca: Cornell University Press.

Picciotto, Sol. 1992. International Business Taxation. A Study in the Internationalization of Business Regulation. New York: Quorum.

Radaelli, Claudio M., and Ulrike S. Kraemer. 2008. "Governance Areas in EU Direct Tax Policy." Journal of Common Market Studies 46 (2):315-36.

Rixen, Thomas. 2008. The Political Economy of International Tax Governance. Basingstoke: Palgrave/Macmillan.

. 2011. "From Double Tax Avoidance to Tax Competition: Explaining the Institutional Trajectory of International Tax Governance." Review of International Political Economy 18 (2):197-227.

2013. "Why Reregulation after the Crisis is feeble: Offshore Financial Centers, Shadow Banking and Jurisdictional Competition." Regulation \& Governance DOI: 10.1111/rego.12024

Ruding Report. 1992. Report of the committee of independent experts on company taxation. Luxemburg: Amt für amtliche Veröffentlichungen der Europäischen Gemeinschaften.

Seligman, Edwin R. A. 1928. Double Taxation and International Fiscal Cooperation. New York: Macmillan.

Sikka, Prem, and Hugh Willmott 2010. "The dark side of transfer pricing: Its role in tax avoidance and wealth retentiveness." Critical Perspectives on Accounting 21(4): 342356.

Steinmo, Sven. 1993. Taxation and Democracy: Swedish, British and American Approaches to Financing the Modern State. New Haven: Yale University Press.

Sullivan, Martin A. 2007. "Lessons from the Last War on Tax Havens." Tax Notes 116 (July 30):327-37.

Surrey, Stanley S. 1978a. "Reflections on the Allocation of Income and Expenses Among National Tax Jurisdictions." Law and Policy in International Business 10 (409):409-60. . 1978b. "United Nations Group of Experts and the Guidelines for Tax Treaties between Developing Countries." Harvard International Law Journal 19 (1):1-65.

Tanzi, Vito. 1995. Taxation in an Integrating World. Washington: Brookings Institution.

van den Tempel, Arnold J. 1967. Relief from Double Taxation: A Comparison of the Work of the League of Nations and of the Organisation for Economic Co-operation and Development. Amsterdam: IBFD.

Vann, Richard J. 1991. "A Model Tax Treaty for the Asian-Pacific Region? (Part I and II)." Bulletin for International Fiscal Documentation 45 (3 and 4):99-111 and 51-63.

Vann, Richard J. 2010. A model tax treaty for the Asia-Pacific region? Sydney, Sydney Law School Legal Studies Research Paper No. 10/ 122. 
Webb, Michael C. 2004. "Defining the Boundaries of Legitimate State Practice. Norms, Transnational Actors and the OECD's Project on Harmful Tax Competition." Review of International Political Economy 11 (4):787-827.

Wilson, John D. 1999. "Theories of Tax Competition." National Tax Journal 52 (2):269-304. 